\title{
Kadavu Island: adaptation and stagnation in the Fijian periphery
}

\begin{abstract}
The outer island of Kadavu is representative of the Fijian periphery. This paper deals with its physical characteristics, infrastructural conditions, and village economic activities with the aim of understanding the changes it has gone through in recent years. A combination of micro-geographic studies in two villages and a meso-geographical analysis show that the pattern of development found in Kadavu in the early 1980s has not changed much. The current pattern of cash crop production and trade is almost entirely dependent on the kava beverage crop, infrastructure is underdeveloped, the island suffers from the peripheral penalty phenomenon, and government initiatives aimed at changing the trend are very limited. However, the current form of non-capitalist production and its derived benefit has forced villagers into a strategy of adaptation which might actually be preferable for them under the current conditions of peripheralization.
\end{abstract}

Keywords

Fiji $\bullet$ Kadavu Island $\bullet$ outer islands $\bullet$ strategy of adaptation $\bullet$ kava

(c) University of Warsaw - Faculty of Geography and Regional Studies

\author{
Michael Sofer \\ Department of Geography and Environment \\ Bar-llan University, Ramat-Gan, \\ Israe \\ e-mail: soferm1@biu.ac.il \\ Received: 1 May 2015 \\ Accepted: 2 June 2015
}

Introduction

Kadavu Island (pronounced Kandavu) and the small islands surrounding it is a province representative of the outer islands, which is, in relative terms, not the remotest place amongst the peripheral areas of Fiji. In previous studies the island was found to represent the Fijian periphery while experiencing limited change over the years (Sofer 1985; 2009). The pattern of cash crop production and trade has been almost entirely dependent on the yaqona (Pacific kava) beverage crop; while shipping services provided from the capital, Suva, have not improved; the island has experienced significant out-migration and government initiatives aimed at changing the trend have been very limited. To an observer of the Kadavu economy it is clear that there are a number of obstacles that affect the local process of development. These obstacles are at the individual, community and regional levels, but they are also related to national mechanisms that have their impact on the island and its native communities.

The purpose of this paper is to look at the pattern of development of Kadavu through a study of issues which characterise the province and its rural communities and to find out whether, at this point in time, the conditions surrounding its peripheral status have changed over time. These issues are being explored through an analysis of its physical and economic conditions, while searching for changes in the survival strategy taken by the local village communities in the last three decades, a process which may signify a certain transformation in the Fijian rural periphery.

The information and data presented in this paper were collected during fieldwork in 1982 and 2013. Two villages were surveyed: the village of Nalotu in the Tikina of Yawe, one of nine administrative provincial subdivisions on the island of Kadavu, and the village of Dravuwalu in the Tikina of Naceva (Figure 1). A household survey based on a questionnaire was conducted, together with interviews with local officials from different government agencies. Data were also collected from published sources, and government ministries and agencies.

The paper moves from a general discussion of the developmental pattern of the outer islands in Fiji, to a discussion of Kadavu Island's physical and economic conditions and to the current village pattern of production. This is followed by an analysis of a number of major obstacles to the process of change and development. The final section is devoted to a discussion on whether the village communities and Kadavu Island as whole have experienced improvement or stagnation.

Issues of development on the outer islands of $\mathrm{Fiji}$

The outer islands, not all of which are at a great distance from the country's core, are perceived to be somewhat different to the main islands: culturally, economically and in terms of infrastructure and service provision, as well as in the degree of adopting modern ways (Connell 2010). Lack of resources brought about a lack of interest during colonial times, which meant that the expansion of capitalism and its mode of production (which affected the larger islands of Fiji), meant little to the outer islands of eastern Fiji (Bayliss-Smith et al. 1988; Sofer 1988). These islands became dependencies of the core and recipients of welfare rather than arenas of economic exploitation. With time, opportunities for local economic development on the outer islands have become limited; mainly due to an indigenous lack of entrepreneurial 
spirit, lack of external or local interest, inadequate infrastructure provision and neglect of governance (Connell 2010). The processes of the larger island's economic attractions and urban bias contributed to out-migration, depopulation, and further economic decline in the Eastern islands of Fiji (Bedford 1980; Brookfield 1980; Bayliss-Smith et al. 1988).

The outer islands of Fiji showed limited economic autonomy, particularly with the decline in the price of copra and the consequential collapse of the copra trade (Overton et al. 1999), although Kadavu Island has benefited from an increase in kava prices and trade (Sofer 2007). Yet, as mentioned by Connell (2010), for numerous places in the Pacific islands states the tyranny of distance has significant disadvantages as the costs of transportation are expensive and have risen over time, and marketing of agricultural products to urban areas has become economically questionable. This is a typical case of peripheral penalty and has been shown in Kadavu, where goods were sold at a higher price in Kadavu village co-operative shops than in Suva (Sofer 2009).

Under these conditions the private sector struggles to survive and the MIRAB model (Bertram 2006) operates across Fiji generally and in Kadavu particularly. Remittances from permanent and temporary migrants continue to constitute a significant source of income for the outer islands of Fiji (Sofer 1992; Felgentreff 1996). The public sector is the major, and in some cases the only, employer of wage labour. Moreover, islands have gone from subsistence to subsidy, depending on the policies and good will of the central state. The outcome is core-periphery relationships and a vicious circle of growing inequalities (Sofer 1988; 2009), under which Kadavu has been a dependent periphery for a significant period of time (Sofer 1985b; 2009).

\section{Major characteristics of Kadavu Province}

\section{Physical conditions}

Kadavu Island and the small islands that surround it comprise one of the four provinces of Fiji's Eastern Division (Figure 1). Kadavu, which accounts for most of the land area of the group, has a surface area of $408 \mathrm{~km}^{2}$, with the total group covering $445 \mathrm{~km}^{2}$, a mere $2.5 \%$ of Fiji's total land surface. Its location is south of the main island of Viti Levu and the sea distance between the capital, Suva, and Vunisea government station, Kadavu's administrative centre, is covered by ferry in six hours on a calm sea, and not less than eight hours in a rough sea. Vunisea can also be accessed by air service from Nausori airport (near Suva) in 45 minutes. Air services operate mainly between Suva and Vunisea, but also from Nadi, which is the only transport link to Kadavu not provided out of the Suva area.

Geologically, the island is a string of ancient volcanic cones and craters that have given rise to its acid rock and tuffaceous sediments (Nunn and Omura 1999). The central spine rises in some places to over $500 \mathrm{~m}$ above sea level and most stream networks drain in the general direction of northwards or southwards, based on small stream catchments (Terry 1999). Most of the island's terrain is rolling through to steep and rugged with an indented coastline that supports a narrow strip of flat land for much of its length. This results in difficulties for the construction of proper road infrastructure. There are reefs all along the island's coastline, which allow larger ferries to anchor in only a limited number of places.

As a result of the rugged terrain and the lack of an overland road network, all but 2 of the 75 villages on the island are located on or within a short distance of the coast. The unsealed road system has been expanding very slowly and is affected by the rugged terrain. Thus internal transportation is sustained mostly by small boats with outboard engines, which cover the distances along the coast. Communication with the main island of Viti Levu is maintained by the inter-island shipping service, which operates out of Suva. This service provides connection mainly to the two jetties available on the northern side of Kadavu: Vunisea, the site of the government station, and Kavala (Figure 1).

\section{Demographic and labour force characteristics}

Kadavu province's population amounted to 10,167 persons in 2007 (Fiji Bureau of statistics 2012). A number of demographic characteristics over a sixty-year period, 1946-2007, are presented in Table 1. The population increased during this period at a relatively slow and irregular pace and its share of the total population of the country declined to a mere 1.2 per cent by 2007 . Two main processes are responsible for the slow rate of growth: fertility decline (which is typical all over Fiji) and out-migration from Kadavu to other provinces in Fiji. The later process is typical of the outer islands as had already been recorded more than three decades ago (Bayliss-Smith et al. 1988). The balance of lifetime net-migration by the 2007 population census specifies a lose of 2875 people (Fiji Bureau of Statistics 2012). Of these, 627 are recent migrants who moved during the five years before the census. The loss of working age population to other areas of Fiji, as well as to overseas destinations, is also reflected in the dependency ratio (the ratio between the depended population and the working age population), which is still much higher than the national average (a value of 900 compared with 699 for the whole of Fiji), suggesting that Kadavu retains relatively more of its younger and older age groups. The out-migration trend may express the population's dissatisfaction with living conditions and economic opportunities in the province. Table 1 also emphasizes the fact that the native Fijian population has always been the dominant component of the provincial population. Finally, the absence of any urban centre on the island suggests that there are very limited local economic opportunities in the secondary and tertiary sectors, most of which are at the government station in Vunisea, the only non-village settlement and the core of public services on the island.

Data concerning Kadavu province's labour force characteristics suggest a relatively high rate of participation. About 77 per cent of the age group 15 to 69 in Kadavu are economically active compared with a national rate of about 56 per cent (Fiji Bureau of Statistics 2012). Clearly, these figures represent a broad labour involvement in (semi)subsistence agriculture. More than 90 per cent of the province's labour force practices this form of agriculture, the majority of which is engaged in such activity without reward in the form of wages or salary. Similar trends may be found in other rural provinces in Fiji, while in the relatively more urbanised provinces subsistence production is mainly practiced as a form of urban agriculture, primarily for home consumption. Moreover, access to paid work in the province of Kadavu is limited and in most cases; apart from government jobs and, more recently, some tourism jobs; all other monetary sources are agriculture-based and either seasonal or part-time.

\section{Infrastructure}

Shipping services. The shipping services to Kadavu are provided mainly by Suva based companies. The government made attempts in the past and even recently, to increase its intervention in the shipping services to the outlying islands, but this has had a limited effect on the extent and quality of services. Although the boats and their capacity have improved in recent years, the pattern and frequency of the current commercial shipping services to Kadavu has deteriorated (Sofer 2009). Two shipping companies serve Kadavu from Suva while there is a complete absence of direct shipping services from other parts of Fiji. The northern part, where the two jetties of Vunisea and Kavala are located, is served more frequently (about 3 times in a 


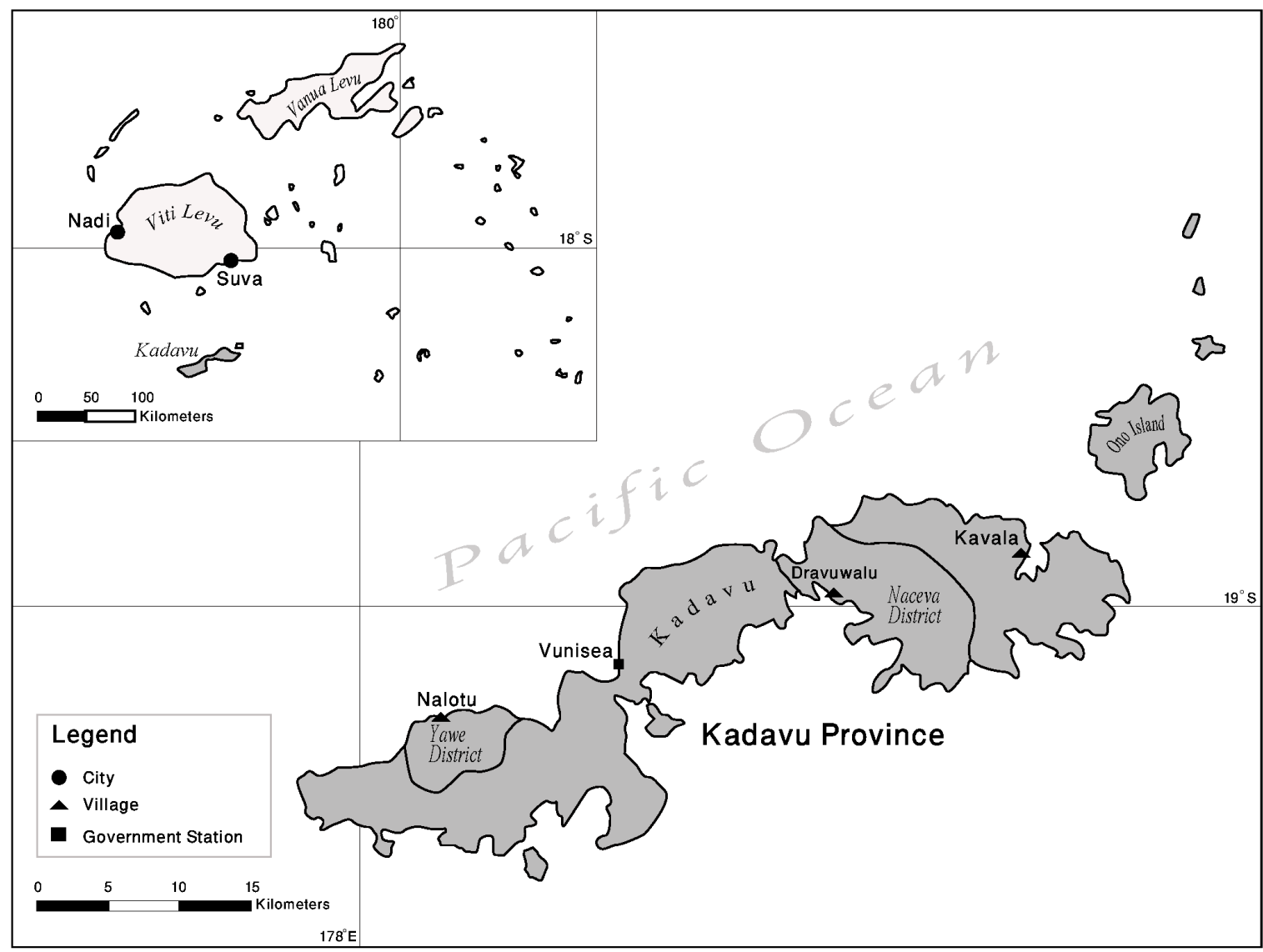

Figure 1. Kadavu island and province - location map

Table 1. Demographic characteristics of the Kadavu province

\begin{tabular}{|c|c|c|c|c|c|c|c|}
\hline Year & 1946 & 1956 & 1966 & 1976 & 1986 & 1996 & 2007 \\
\hline \multicolumn{8}{|l|}{ Population } \\
\hline Total population & 7229 & 7450 & 8631 & 8699 & 9805 & 9535 & 10167 \\
\hline$\%$ of Fiji's total population & 2.8 & 2.2 & 1.8 & 1.5 & 1.4 & 1.2 & 1.2 \\
\hline Kadavu dependency ratio & 1014 & 1058 & 1173 & 1049 & 949 & 992 & 900 \\
\hline Fiji dependency ratio & 1039 & 1045 & 1023 & 825 & 754 & 672 & 699 \\
\hline \multicolumn{8}{|l|}{ Ethnic composition } \\
\hline 1. Fijians & 6971 & 7246 & 8426 & 8537 & 9630 & 9413 & 9964 \\
\hline 2. Indians & 20 & 17 & 3 & 7 & 46 & 48 & 49 \\
\hline 3. Others & 238 & 187 & 202 & 115 & 129 & 74 & 154 \\
\hline Urban population & 0 & 0 & 0 & 0 & 0 & 0 & 0 \\
\hline
\end{tabular}

Sources: Respective population censuses: Gittins 1947; McArthur 1958; Zwart 1968; Lodhia 1977; Navunisaravi 1988; Bainimarama 1998; Fiji Bureau of Statistics 2012. 
fortnight), but there are no regular services to the southern part of the island. The two jetties assist in the centralization of the distribution and collection of cargo to and from adjacent villages, and the internal services are based on small outboard motorboats. The outcome is that high transportation costs are imposed on the villagers in order to reach the major markets within the country, which means that in the increasingly competitive environment that has evolved in the Fijian economy, the ability of Kadavu's producers to respond efficiently to market demand is constantly being hampered. The current services do not encourage Kadavu's farmers to try and compete on the lucrative markets in Fiji with a diversity of crops other than kava.

Transportation within Kadavu. According to the "Kadavu Development Plan 2013-2017" the road system is 92 kilometres long, available mainly on the western part of the island, and comprises of unsealed roads that have been expanding very slowly. The road system is unreliable and frequently affected by natural hazards such as heavy rains. Public transport is unavailable and most of the internal transportation is sustained by small, privately owned boats. There are high costs of transportation within Kadavu. A land distance of 1 kilometre between the jetty and the government station in Vunisea may cost FJD20 1, and a road distance of 43 kilometres between Vunisea and Nabukelevuira, a village on the Western end of the island, may cost FJD300 (Kadavu Development Plan 2013). Travelling by small boat to a village one hour away from Vunisea may cost between 70 and 200 FJD. The consequence of this is that a serious "peripheral penalty" has been affecting Kadavu and for farmers who are willing to export their produce, the cost of transportation to the loading point can be very high.

Power, water and communication. Electric power is limited. In the village of Dravuwalu there is a generator operating during the early evening for only two hours. The operation costs are covered by the villagers. In Nalotu village there has been an innovation - solar panels, which were donated to the villagers and are available on all houses, but these are not well maintained. The water system has improved since the early 1980s, yet water taps are located mainly outside houses and carrying water to the kitchen is a frequent practice. There is no proper sewerage system which is accompanied by all the hygiene issues related to these conditions.

An additional innovation that has appeared in Kadavu villages in the last few years is a mobile network. Despite the "Kadavu Development Plan 2013-2017" reporting limited mobile network coverage, the role of the mobile telephone in village life is tremendous. It allows a visitor like me to coordinate his visit much more easily. Moreover, the telephone enables the local villager to check the price of yaqona (kava) in Suva market and to react to the changing demand and supply on the markets.

\section{The economy}

The island of Kadavu was incorporated into the cash economy mainly through the selling of copra and food crops. The sale of food crops was of relative importance in late 19th century when the island served as a port of call for the Pacific steamer lines from Sydney to San Francisco (Thomson 1889). Copra was an important cash earner for Kadavu for a long time, but in the 1980 s its importance declined significantly (Sofer 1985a). New crops such as vegetables were introduced on a commercial basis in the late 1930s and revived several times but have never been a considerable commercial success. It is kava (yaqona in Fijian), a species of the pepper family (Piper methysticum), which has developed into the role of a major cash crop. This plant is the source of the South Pacific kava that is the traditional beverage

${ }^{1}$ Fijian dollar equals 0.5 U.S. dollar. of Pacific islanders (Simeoni and Lebot 2014). This beverage is used frequently at various social gatherings as well as a pastime. Kava had been a cash crop in the 1930s, but its importance has significantly increased and it is now the paramount cash earner for Kadavu villagers (Sofer 1985; 2007).

\section{The village production pattern}

Discussion in this section concentrates on the household as the unit of analysis and is based on the assumption that decisions taken concerning production (and consumption) are determined by the household survival strategy. Moreover, the household is the building block of the village economy. Above it is the extended family (i-tokatoka) and a further stage above that is the clan (mataqali). The reason is that the household has a tendency to remain relatively resilient and robust through time and its strategy, though embedded in a communal framework, is dictated by the individual members of the household.

Kadavu villagers practice semi-subsistence agriculture where both subsistence and commercial production are evident, and maintain a strong foundation in subsistence diversity by growing a wide range of crops in their gardens (Kuhlken 2002; 2007). Table 2 compares the proportion of farms growing major crops and livestock in the villages of Nalotu and Dravuwalu (Figure 1), over two different periods at an interval of more than 30 years (1982 and 2013). For both periods the most common crops are traditional root crops grown under shifting cultivation methods, where the length of the cultivation period for a given field, before being left fallow (commonly three years in Kadavu), is often determined by the duration of yaqona cultivation. As shown in table 2, in 2013 all households in both villages produced yaqona while in Nalotu all households also produced the traditional root crops, this compared with a decline in interest for cassava in Dravuwalu. The most significant change is the appearance of modern vegetables, which have never had a notable commercial success. There is a clear decline in the number of households who raise livestock but not necessarily in livestock numbers, as the number of pigs in the villages has increased significantly. The data recorded in the survey show that the technology used is simple and based mainly on manual tools where the spade, fork

Table 2. Percentage share of village farms growing various crops and livestock, 1982 and 2013 (\%)

\begin{tabular}{|c|c|c|c|c|}
\hline & \multicolumn{2}{|c|}{ Nalotu } & \multicolumn{2}{c|}{ Dravuwalu } \\
\hline Crops & $\mathbf{1 9 8 2}$ & $\mathbf{2 0 1 3}$ & $\mathbf{1 9 8 2}$ & $\mathbf{2 0 1 3}$ \\
\hline Yaqona (kava) & 95 & & & \\
\hline Cassava & 95 & 100 & 96 & 100 \\
\hline Yams & 95 & 100 & 31 & 25 \\
\hline Dalo & 91 & 100 & 100 & 96 \\
\hline Modern vegetables & 5 & 25 & 0 & 14 \\
\hline & & & & \\
\hline Livestock & & & & \\
\hline Pigs & 95 & 77 & 73 & 29 \\
\hline Poultry & 77 & 46 & 85 & 50 \\
\hline Goats & 14 & 12 & 4 & 0 \\
\hline Cattle & 23 & 0 & 12 & 4 \\
\hline
\end{tabular}

Note: The number of households surveyed: 1982: Nalotu - 22 ; Dravuwalu - 26 2013: Nalotu - 26 ; Dravuwalu - 28 Sources: Sofer 1985b; Fieldwork 2013 
MISCELLANEA GEOGRAPHICA - REGIONAL STUDIES ON DEVELOPMENT

Vol. $19 \cdot$ No. 2 - 2015 • pp. 14-20 • ISSN: 2084-6118 • DOI: 10.1515/mgrsd-2015-0006

Table 3. Average percentage share of end use of household production 2013 (\%)

\begin{tabular}{|c|c|c|c|c|c|c|}
\hline \multirow[b]{3}{*}{ Product } & \multicolumn{6}{|c|}{ Percentage of end use of production } \\
\hline & \multicolumn{3}{|c|}{ Nalotu } & \multicolumn{3}{|c|}{ Dravuwalu } \\
\hline & Subsistence & Exchange & Cash & Subsistence & Exchange & Cash \\
\hline Yaqona & 9.6 & 9.2 & 81.2 & 11.1 & 9.8 & 79.1 \\
\hline Dalo & 76.9 & 21.0 & 2.1 & 69.4 & 21.9 & 8.7 \\
\hline Yams & 89.0 & 11.0 & 0 & 91.2 & 8.8 & 0 \\
\hline Cassava & 80.8 & 19.2 & 0 & 93.8 & 6.2 & 0 \\
\hline Vudi (Plantain) & 97.7 & 2.3 & 0 & 100 & 0 & 0 \\
\hline Vegetables & 83.3 & 1.7 & 15 & & & \\
\hline Fish & 92.1 & 5 & 2.9 & 77.1 & 6.2 & 16.7 \\
\hline Polutry & 93.9 & 6.1 & 0 & 84.5 & 15.5 & 0 \\
\hline Pigs & 76.4 & 8.7 & 14.9 & & & \\
\hline Handicrafts & 57.1 & 12.9 & 30 & & & \\
\hline
\end{tabular}

Source: Fieldwork 2013

and bush knife are the main items that most households own. Only a limited number of households use chemical pesticides, herbicides or fertilizers, some of which are part of modern vegetable cultivation methods.

Analysis of the percentage share for the end use of major crop production and livestock for the two villages (Table 3) emphasizes the importance of yaqona as the major cash crop, with more than 70 per cent of its yield being sold. By comparison, all other crops are mostly used locally, either for domestic consumption or traditional exchange. The second item on the cash list is handicrafts in Nalotu (unimportant in Dravuwalu), which is based on women's labour and the tendency among households producing them is to sell about 30 per cent of what is produced. Regarding livestock, only about one sixth of the number of pigs are sold by Nalotu villagers. Fish are sold to a certain extent by Dravuwalu villagers. The absence of any other major agricultural item is very much related to the accessing of shipping services that has been discussed above.

The percentage distribution of the various sources of cash income for the villages of Nalotu and Dravuwalu (Table 4) emphasises the increasing importance of agriculture by 2013 , among which yaqona is the prominent source of income, and the declining role of non-agricultural activities, including remittances. The latter seems to have been underestimated by reporting households in 2013 and should still be regarded as an important source of income and support for villagers' level of welfare. The flow of remittances allows villagers to retain a consumption pattern that can't be achieved by relying only on local production, and is a common practice in the Pacific islands. The "other" source of income (Table 4) contains, in the case of Dravuwalu, a new venture - the collection and sale of Bêche-demer (sea cucumber) to an employee of a Suva based merchant who is located in the village. This trade, where China is the main market, used to be a major trade item in the early colonial period before disappearing but has recently reappeared. Currently, its contribution to the villagers' income is very limited.

\section{Economic potential and current obstacles}

The economic potential of Kadavu Island, as it is considered by the provincial administration, appears in Table 5. The leading asset is yaqona production. Fishing, a natural asset for an island world, is under-exploited as a result of the lack of appropriate marketing services including a means of refrigeration and efficient transportation. Pine has been planted since the 1970s
Table 4. Percentage distribution of sources of cash Income, 1982 and 2013 (\%)

\begin{tabular}{|c|c|c|c|c|}
\hline & \multicolumn{2}{|c|}{ Nalotu } & \multicolumn{2}{c|}{ Dravuwalu } \\
\hline Source of income & 1982 & 2013 & 1982 & 2013 \\
\hline Agriculture and fishing & 21.8 & 73.7 & 44.1 & 74.8 \\
\hline Handicrafts & 5.1 & 8.3 & & 1.4 \\
\hline Remittances & 47.5 & 11.3 & 7.5 & 12.4 \\
\hline Wages & 21.9 & 2.5 & 42.0 & 1.4 \\
\hline Business & & 2.3 & & 2.7 \\
\hline Other & 3.7 & 1.9 & 6.4 & 7.3 \\
\hline Total & 100 & 100 & 100 & 100 \\
\hline
\end{tabular}

Source: Fieldwork 2013

Table 5. Estimated existing annual economic potential in millions of FJD

\begin{tabular}{|c|c|c|}
\hline Sector & $\begin{array}{l}\text { Potential annual } \\
\text { value } \$ \mathrm{~m}\end{array}$ & Comments \\
\hline Yaqona & 22.0 & $\begin{array}{l}\text { Other crops can be } \\
\text { tapped }\end{array}$ \\
\hline Fisheries & 4.5 & $\begin{array}{c}\text { Required sustainable } \\
\text { managment }\end{array}$ \\
\hline Pine & 6.4 & $\begin{array}{l}\text { Other native timber } \\
\text { included }\end{array}$ \\
\hline Tourism & 1.5 & $\begin{array}{l}\text { Enhancement of the } \\
\text { industry is considered }\end{array}$ \\
\hline Business & 20.2 & $\begin{array}{l}\text { Retail, canteen, selling } \\
\text { petroleum }\end{array}$ \\
\hline Rural Banking & 1.0 & \\
\hline Total & 55.6 & \\
\hline
\end{tabular}

Source: Kadavu Development Plan 2013

and there are 8 pine schemes ready for harvest. But the ability to get to the plantations on the top of cliffs and mountains without a proper road system is very much questionable. Tourist resorts 
appeared in Kadavu in the early 1980s, and 1,638 tourists visited the province in 2012 and were accommodated in the 7 operating resorts. This number can be increased.

According to the "Kadavu Development Plan 2013-2017" the province has great economic potential that has been overlooked over the years. The annual economic value of Kadavu production, estimated at this point in time to be about 55 million FJD, can be doubled or even tripled if the 5 year plan (amounting to FJD19.8 million) is funded. The socio-economic benefit of this plan should enhance "good governance, the engagement of women in development, reverse urban drift, reduce poverty, minimise school dropouts, improve health, eradicate dependency syndrome, promote self sufficiency, enhance sustainability and improve livelihood". However, this Development Plan emphasises a variety of obstacles to the implementation and realisation of the full potential of Kadavu province. Firstly, there is no sustainable resource utilisation plan in the three major categories: land, marine resources, and human capital. Second, there is no community capacity building programme in terms of leadership and governance. One of the major expectations is that the 9 Tikina Council Forums have all given their consent to this Plan.

\section{Discussion and conclusions}

Generally, studying changes in rural communities in the developing world is a search for indicators suggesting transformations on the path towards a desired development (Vandergeest and Rigg 2012). Among these indicators we may find a decline in the share of labour force involved in direct farming activities, rising levels of agricultural diversification, an increase in non-farming activities among rural households, a shift from subsistence to market orientated production, enhanced ruralurban economic relations and greater state support in rural development. There are also cases where we may find limited changes, yet this does not necessarily mean a failure to go through a positive transformation process.

Fiji has been undergoing a social and economic transformation process at the national level for a significant number of years, nevertheless some communities, particularly in the outer islands, may stick to the peasant form of production. This phenomenon, common in other parts of the developing world, may be indicative of the continued vitality, under adaptation, of the peasantry production mode. This is the result of a lack of a local and regional development process that may offer alternative sources of income. This may also indicate the development of a survival strategy which enables villagers to develop additional sources of income, allowing them to respond to an increase in the rate of consumption while the rate of production has not significantly changed or is still lagging behind.
A main characteristic of the peasantry production mode in Kadavu villages, as recorded in Nalotu and Dravuwalu, is that a major part of the cultivation process is based on communal use of labour force by operating household gardens in groups along clan lines and shifting daily between these gardens. These communities, representative of the Kadavu population, are commonly defined as traditional communities whose customs, self-sufficiency level, and ecological stewardship practices are still in place and still operating. This doesn't mean that Kadavu Island is not linked to the market economy. It is linked and even responds by further entrenching itself in Kava production, thus being dependant on an export commodity that is consumed outside the island.

At the same time Kadavu's population is still waiting for capital infrastructure such as an enlarged and better road system, jetties, electricity, telephone, among others, which create a better environment for advanced economic activities. Road networks and jetties to provide access and shipment of produce to the markets. Infrastructure which will allow the exploitation of potential resources that are owned by the people of Kadavu including rich marine and land resources, as well as resources owned by the individual communities - human resources. What is also required now, in order to avoid further marginalisation of Kadavu province, are influential leaders who can drive the development of its people.

Taking into account the view that peasants and peasantry will not disappear, and that the islanders will not become parttime farmers with their income relying on an increasing number of sources, local development leaders should raise a question about the entrepreneurial spirit of the villagers. How an entrepreneurial spirit can be initiated, encouraged and propagated as a major tool for local development. How a subsistence farmer can be changed into an entrepreneurial commercial farmer. Peasants will not disappear but their form of production and of making a living can be improved leading to higher income levels and better access to goods and services - conditions which all of us define as development.

This study shows that rural change, as it appears to any degree and extent, cannot be fully understood simply by pointing at a shift from rural traditions towards modernity, by shifting away from self-sufficiency towards a market economy, from communalism to individualism and from high degree of inequality towards some degree of equality. These specific indicators and trends assist us in understanding particular situations, but not necessarily the full transformation processes and their underlying mechanisms. The latter is crucial in studying rural change and its effects on the rural society.

\section{References}

Bainimarama, T 1998, 1996 Fiji Census of Population and Housing, Parliament of Fiji, Parliamentary Paper No. 43 of 1998, Bureau of Statistics, Suva.

Bayliss-Smith, TP, Bedford, R, Brookfield, H, \& Latham, M 1988, Islands, Islanders and the World: the Colonial and Post-Colonial Experience of Eastern Fiji, Cambridge University Press, Cambridge.

Bedford, RD 1980, 'Demographic processe in small islands: The case of internal migration' in Population-Environment Relations in Tropical Islands: The Case of Eastern Fiji ed HC Brookfield, MAB Technical Notes 13, UNESCO, Paris, pp. 29-59.

Bertram, J 2006, 'Introduction: The MIRAB model in the twentyfirst century', Asia Pacific Viewpoint, Vol. 47, no. 1, pp. 1-13.
Brookfield, HC (ed) 1980, Population-Environment Relations in Tropical Islands: The Case of Eastern Fiji, MAB Technical Notes 13, UNESCO, Paris.

Connell, J 2010, 'Pacific islands in the global economy: Paradoxes of migration and culture', Singapore Journal of Tropical Geography, Vol. 31, no. 1, pp. 115-129.

Fiji Bureau of Statistics 2012, Key Statistics: September 2012, Fiji Bureau of Statistics, Suva.

Felgentreff, C 1996, 'Migration and remittances in the eastern periphery of Fiji: the case of Naikeleyaga village', Asian Migrant, vol. 9, no. 1, pp. 21-27.

Gittins, JW 1947, A Report on the Results of the Census of the Population, 1946, Legislative Council of Fiji, Council Paper No. 35 of 1947, Suva. 
Kadavu Development Plan 2013-2017, 2013, Office of Provincial Administrator Kadavu.

Kuhlken, R 2002, 'Intensive agricultural landscapes of Oceania', Journal of Cultural Geography, vol. 19, no. 2, pp. 161-95.

Kuhlken, R 2007, 'Agricultural landscapes of Kadavu: Persistence and change on the Fijian periphery', in Environment, Development and Change in Rural Asia Pacific, J, Connell, \& E, Waddell E, Routledge, London, pp 56-75.

Lodhia, RN 1977, Report on the Census of the Population 1976. Parliament of Fiji, Parliamentary Paper No. 13 of 1977 , Suva.

McArthur, N 1958, Report on the Census of the Population, 1956, Legislative Council of Fiji, Council Paper No. 1 of 1958, Suva.

Navunisaravi, WB 1988, Report on Fiji Population Census 1986, Parliament of Fiji, Parliamentary Paper No. 4 of 1988 , Bureau of Statistics, Suva.

Nunn, PD \& Omura, A 1999, 'Penultimate interglacial emerged reef around Kadavu Island, southwest Pacific: implications for late Quaternary island-arc tectonics and sea-level history', New Zealand Journal of Geology and Geophysics, vol. 42, no. 2, pp. 219-227.

Overton, J, Murray, W, \& Ali I 1999, 'Commodity production and unsustainable agriculture', in Strategies for Sustainable Development. Experiences from the Pacific, eds J, Overton, and R, Scheyvens, UNSW Press, Sydney, pp. 168-84.

Simeoni, P, \& Lebot, V 2014, Buveurs de Kava, Geo-Consulte, Port Vila, Vanuatu.

Sofer, M 1985a, 'Yaqona and peripheral economy', Pacific Viewpoint, vol. 26, no. 2, pp. 415-436.
Sofer, M 1985b, 'The dependency paradigm applied to the Fijian periphery', The Singapore Journal of Tropical Geography, vol. 6 , no. 2, pp. 127-138

Sofer, M 1988, 'Core-periphery structure in Fiji', Environment and Planning D: Society and Space, vol. 6, no. 1, pp. 55-74.

Sofer, M 1992, 'Labour circulation and the village economy in Fiji', The Singapore Journal of Tropical Geography, vol. 13, no. 2, pp. 118-129.

Sofer, M 2007, 'Yaqona and the Fijian periphery revisited', Asia Pacific Viewpoint, vol. 48, no. 2, pp. 234-249.

Sofer, M 2009, 'Twenty Years of Change in the Fijian Periphery: The Case of the Kadavu Island, Fiji', Singapore Journal of Tropical Geography, vol. 30, no. 3, pp. 343-357.

Terry, JP 1999, 'Kadavu Island, Fiji - fluvial studies of volcanic island in the Humid Tropics', Singapore Journal of Tropical Geography, vol. 20, no. 1, pp. 86-98.

Thomson, JP 1889, 'The island of Kadavu', Scottish Geographical Magazine, vol. 5, pp. 638-652.

Vandergeest, P, \& Rigg, J 2012, 'The restudy "problem" and agrarian change: Revisiting rural places in Souteast Asia', in Revisiting Rural Places: Pathways to Poverty and Prosperity in Southeast Asia, eds J, Rigg, and p, Vandergeest, NUS Press and the University of Hawaii Press, Singapore and Manoa, pp. 1-24.

Zwart, F 1968, Report on the Census of the Population, 1966, Legislative Council of Fiji, Council Paper No. 9 of 1968, Suva. 